\title{
TEACHING VIETNAM AS HISTORY
}

Joe P. Dunn

Converse College

The Vietnam War has made the transition from current event to recent history. After a period of waning interest, the topic has revived on the college campus. The military academies and senior colleges, who for a brief time in the seventies dropped Vietnam from their programs, have restored the subject. Significant scholarship is proliferating and a resurgence in the classroom is evident. Social scientists employ Vietnam as a case study in a wide range of courses, and the historian is asserting his claim to the topic. In research, historians are relooking at the events of the war, attempting early assessments of the experience, and addressing the "lessons of Vietnam." In the classroom, the war is being integrated into courses on diplomatic, military, and recent United States history. Some history departments have complete courses on Vietnam. It is still early, and time and distance may yet be needed for perspective, but the time for the historian to move to the forefront of the study of Vietnam has arrived.

Beginning with the teach-ins of 1964-1965, Vietnam invaded the college campus, the classrooms as well as the streets. Departments from the hard sciences to religion and philosophy offered Vietnam-related courses. The politics, history, economics, ethics, psychology, sociology, and technology of the war were studied. Although some courses were scholarly undertakings, many were little more than activist-oriented polemics solely dedicated to mobilizing opposition to the war. With the end of the war, Vietnam virtually disappeared from the college classroom.

The academic rebirth today is important. The topic is vital and the contemporary climate is conducive to more dispassionate and meaningful study. The moralistic rhetoric and apocalyptic tones of the sixties have subsided. Events have demonstrated that America's anguish and self-abasement were overdrawn. We were neither as selfless as proclaimed by our leaders, nor as evil as asserted by the angry protestors. The limits of our power and our vulnerabilities are more evident. Our vital national interests are more clear. The wounds and divisiveness have healed and a patriotic spirit appears more prominent.

Equally important, a new generation of students does not remember the war. The college student of today was born in the last years of the fifties or in the early sixties. Most of our present students were in junior high, or even in grade school, when Richard Nixon resigned the Presidency. Within a couple of years, young people who were born during the Johnson administration will enter college. Our present students were young children during the sixties. Those of us who vividly experienced the decade, seemingly such a brief time ago, often overlook this fact. We often assume knowledge which these youth must acquire through formal study.

But the study of Vietnam has many values beyond merely passing on the events of a decade to another generation. Few topics better capture the forces of the twentieth-century world. The long range origins of the Vietnam situation are a product and a classic example of foreign imperialism and European colonialism. In Vietnam we see all the developmental problems of the underdeveloped world. Vietnam experienced the typical religious, ethnic, social, and cultural conflict of Third World countries. The country affords an excellent opportunity to study the ascendency of nationalism, revolution, and communism in the colonial areas of the globe. In the era between the world wars (probably the most significant for understanding Vietnam), we witness the weakness and failures of Wilsonian liberalism and the appeal of Marxism-Leninism to young Third World nationalists. Ho Chi Minh is a representative example. Finally, in Vietnam we 
follow the growth of the Comintern and the patterns of Soviet activity during a crucial period of the expansion of Soviet influence.

Another dimension of the twentieth century unfolded in the World War II and postwar era as Vietnam became a victim of great power confrontation and the cold war. Passed back and forth among France, Japan, Britain, China, France again, and finally the United States, Vietnam became a pawn in the struggle for world status and influence. As the cold war intensified and containment spread from Europe to the far reaches of the globe, Vietnam became a battleground. Nowhere is the American transition from anti-colonialism to anti-communism better demonstrated than in Indochina. Vietnam offers a microcosm of the changes and continuities of the Roosevelt, Truman, and Eisenhower-Dulles foreign policy objectives and approaches. This increasingly entailed alliance with unrepresentative, unpopular, and ineffective regimes (first Bao Dai and then Ngo Dinh Diem), the clandestine machinations of the CIA, the squandering of millions of U.S. aid dollars, and the other frustrations of maintaining an anti-communist client state. Finally, Vietnam offers a clear example of the failure of containment and of the impotence of American nuclear supremacy in crises in the Third World arena.

A host of important issues from the sixties demand attention. The military conduct of the war is not unimportant and military historians will find a rich area of inquiry here. But the political, diplomatic, and social aspects are more important for most undergraduate liberal arts students. Of greatest importance is the process of too rapid (and forced) modernization which Vietnam experienced. While this did not begin in the sixties, it significantly accelerated in the decade. In South Vietnam the American impact forced political, social, economic, and cultural changes which transformed traditional society (see FitzGerald below). The parallels with Iran under the Pahlavis are instructive. The forced communization of North Vietnam during the fifties and sixties evokes previous models in the Soviet Union, Eastern Europe, North Korea, and China, and more recent experiences in Ethiopia, Cambodia, and Afghanistan.

Vietnam is an excellent case study in recent American foreign policy/ national security process. It demonstrates the various factors, realistic and unrealistic, strategic and tactical, domestic and foreign, and the purely political, which dominate the policy process. It shows the variance between policy and execution. But most of a11, it illuminates the frustration of conducting policy. Certainly it affords a key test of the policies and effectiveness of the three administrations dominated by the war; and all three, to one degree or another, failed the Vietnam test.

The internal domestic dimensions of the war made it an important area of social and intellectual study. The Black revolution, the youth culture/student protest movement, and radical activism all had pre-war roots. The rebellion of the sixties would have occurred without the war, but Vietnam exacerbated the trauma of the decade. It provided a central issue and a unifying theme for the alienated, radicalized youth of the decade. No course on Vietnam can ignore the New Left, or Movement as the protest element was loosely styled, and the dynamics of the anti-war phenomenon.

Ultimately, the final objective of the study of Vietnam must be to reflect upon the total experience and to contemplate the lessons. This is a difficult, and it can be a dangerous, enterprise. One of the great problems of the Vietnam War was the tendency to apply the supposed lessons of World War II and Korea. Just as the the overworked Munich analogy has been inappropriate to most of the situations to which it has been applied, the lessons of the two previous wars simply did not apply to Indochina in the sixties and seventies. Henry Kissinger probably says it best in his revision of the tired old Santayana cliche on ignoring the lessons of history: 
History is not, of course, a cookbook offering pretested recipes. . . It can illuminate the consequences of actions in comparable situations, yet each generation must discover for itself what situations are in fact comparable. No academic discipline can take from our shoulders the burden of difficult choices. 1

Gaddis Smith goes even further: "One of the most somber aspects of the study of history is that it suggests no obvious ways by which mankind could have avoided folly."2

With these warnings in mind, we must attempt, nevertheless, to garner something from the Vietnam experience. But what? The lessons of Vietnam vary according to one's perspective, one's starting assumptions. Hawks proclaim the proven bankruptcy of limited war and political restraints upon military necessities. As Barry Goldwater challenged in 1964, why not military victory? Doves counter that the war was never viable and the end only proved the obvious. Liberals focus upon the mistakes and errors, differing among themselves whether these were the product of misperception and bungling or of a more rational and calculated decision process.

The wide array of lessons is too vast to examine here. The literature on the subject is exhaustive. The list of books runs into the hundreds; articles into the thousands. Many works are marginal, transient, or outdated; too many suffer the ills of "presentism," "instant history," or the radical fad of the sixties. Yet several will stand the test of time and remain significant contributions. All students of Vietnam should be introduced to some of the seminal works which address overriding lessons. 3

But the first step should be to choose a text. Most of the early Vietnam texts are out of print. These include the works of Joseph Buttinger, the prolific Austrian scholar who was a student of Vietnam long before the American phase of war. Buttinger's The Smaller Dragon (1958) and his two-volume Vietnam: A Dragon Embattled (1967) surveyed Vietnam's long history from earliest traces to the mid-sixties. Unfortunately, neither of these volumes nor his single-volume condensation, Vietnam: A Political History (1968), are available today. Only his brief Vietnam: The Unforgettable Tragedy (1977) remains in print; and it is a polemic differing markedly from the objectivity of its predecessors. George H. Kahin's and John W. Lewis's The United States in Vietnam (rev. ed., 1969), the best-selling anti-war text of the late sixties and early seventies, and Chester Cooper's excellent memoir and survey of the fifties and sixties, The Lost Crusade (1970), are no longer available. Bernard Fa11, America's leading expert on Vietnam before his untimely death in Vietnam in early 1967, wrote several books which remain the standards on Vietnamese society and politics in the fifties and sixties. Although most are too chronologically narrow and specialized to serve as a text, his Last Reflections on a War (1967), a posthumously published collection of short pieces written over his career, is an excellent companion to a text.

The best available short paperback texts on American involvement are Peter A. Poole's Eight Presidents and Indochina (1978), a brief but adequate survey with minimal interpretation, and George C. Herring's more interpretative America's Longest War (1979). Alexander Kendrick's The Wound Within (1974), which focuses on the internal impact of Vietnam on America, ends with the Paris Accords of 1973. It is interesting, but its eclectic detail and continual asides tend to overwhelm the novice student. Hugh Higgins's Vietram (1975) is mediocre at best. Michael Charlton's and Anthony Moncrieff's Many Reasons Why: The American Involvement in Vietnam (1978), a compendium of interviews, is valuable. Allan R. Millett's A Short Histary of the Vietnam War (1978), a collection of twelve articles from "end of the war supplements" in the 
Washington Post in 1973 and 1975, is a useful companion piece. William L. Griffen and John Marciano's Teaching the Vietnam War (1979) is a disappointing polemic. 4

Moving beyond the "text" to more thematic, interpretative works, three books stand above the rest. Frances FitzGerald's Fire in the Lake (1972), David Halberstam's The Best and the Brightest (197/2), and Leslie Gelb's and Richard Betts's The Irony of Vietnam (1979) may not necessarily be the best books on Vietnam, but each is a classic expression of a theme, an interpretation, which holds a significant place in the historiography of Vietnam. Every student of Vietnam should confront the "lessons" of these interpretations.

No book on Vietnam has received the attention of Fire in the Lake. Winner of such coveted awards as the Pulitizer Prize, the National Book Award, and the Bancroft Prize in History, it was also a best seller (although one suspects that, as with many such best-sellers, the book was far more purchased than read). Drawing upon the work of her academic mentor, sociologist Paul Mus, the world renowned French expert on Vietnamese religion and culture, FitzGerald argued that the failure of the United States was the inability to understand the Vietnamese, their traditional culture and society, and the revolutionary process sweeping the country. While the National Liberation Front operated in accord with the Vietnamese social structure and the Confucian tao, the United States and the westernized Government of (South) Vietnam (GVN) attempted to mold a traditional Asian society into an American image. The results were inevitable and tragic, according to FitzGerald.

The book has several flaws both in understanding the Vietnamese and American policy and actions. Although seemingly well versed in the literature of Chinese and Vietnamese society and a veteran of two journalist tours in Vietnam, FitzGerald does not know the Vietnamese nearly as well as she attempts to portray. As one reviewer, a noted scholar on Vietnam, states:

. . the author's depiction of Vietnamese national character is little short of disasterous. After all, even under the best of conditions, such generalization is risky business. . . the author of Fire in the Lake knows neither the language nor the literature of the people whom she intends to characterize. . .

Why Frances FitzGerald feels the need to generate a grand Vietnamese Gestalt is unclear. Ironically, although she posits a Vietnamese "state of mind" totally alien to that of her American readers, it is to Western writers like Sigmund Freud, Max Weber, 0. Mannoni and Paul Mus that she harkens for basic interpretations. Where these are insufficient, there is always an inappropriate quotation from the fashionable I Ching, or Book of Changes (from whence comes "Fire in the Lake," a metaphor for revolution). Thus it is that her explanation of the relationship between Vietnamese father and son sounds more like a cross between middle class Austrian family patterns of the late 19th century and Lin Yutang's facile renditions of aristocratic Chinese norms, than it does anything I have ever observed or read about in Vietnam. 5

Still FitzGerald's though-provoking argument is a perspective which every student of Vietnam should confront.

Although not quite as highly touted as Fire in the Lake, Halberstam's The Best and the Brightest, published in the same year, received its share of acclaim. Halberstam expands upon the classic liberal "quagmire" theme 
eloquently expressed earlier by Arthur Schlesinger, Jr., in The Bitter Heritage (1966). In this liberal view, the war was a mistake, the product of incorrect premises, wrong decisions, error, misperception, weak policy process, poor leadership, and/or bungling. Halberstam found the core of the problem, the descent into the quagmire, in the policy process and the men who made American foreign policy.

Products of the cold war mentality, the policy elites, like the Presidents they served, suffered from idealism, machoism, hubris, and an excessively optimistic "can do" mentality. These intellectual, driving, success-oriented managers, "the best and the brightest" that the nation had to offer, believed unquestionably that commitment and will would bring success. According to Halberstam, American policy was neither sinister nor self-seeking. Certainly it was not the product of a grand design for imperialist world hegemony arising from the demands of capitalism, as radicals proclaimed. Rather, American actions were mechanistic, incremental, hopeful. The inertia of the next logical step dominated policy-making. Through the book's fascinating vignettes and mini-biographies of policy elites, Halberstam's indictment of men and decisions, the cold war mentality, and the elitist policy process is clear. Although the theme is overplayed, the book is an interesting and valuable perspective on Vietnam and all of American postwar foreign policy.

Gelb and Betts, The Irony of Vietnam: The System Worked, to my mind the best single explanation of the war now in print, directly challenges the Halberstam "quagmire" perspective. Pursuing a thesis first offered by Daniel Ellsberg's Papers on the War (1972), Gelb and Betts contend that the United States did not stumble and sink into the Vietnam quagmire through miscalculations, inadequate policy process, and limited policy options. On the contrary, the authors argue that the decision process functioned well, providing wide options and accurate assessments of the costs, probabilities for success, and implications of the various alternatives. The problem came not from the process but from the conscious choices made by policy makers with the options and alternatives clearly before them.

Washington attempted to wear down the enemy at the least cost; political leadership wanted the fruits of military victory without paying the costs of winning one. John Kennedy and Lyndon Johnson consciously and repeatedly opted for alternatives calculated as the minimal steps necessary not to lose. They strived to hang on until a formula for an acceptable negotiated peace could be achieved. This strategy of incremental escalation, against the advice of many senior military advisors, played into Hanoi's hands. Neither Kennedy, Johnson, nor Nixon ever fully appreciated Hanoi's total resolve and complete commitment to ultimate victory. Hanoi's protracted war strategy, manipulation of the U.S. with hints of progress in the peace process, and effective public relations, made the war increasingly costly to the United States in lives, finances, and declining public support. Allan E. Goodman, The Lost Peace: America's Search for a Negotiated Settlement of the Vietnam War (1978), expands upon Hanoi's successful use of the negotiation process. Conversely, Gareth D. Porter, A Peace Denied: The United States, Vietnam, and the Paris Agreement (1975), credits the communists with negotiating in good faith and blames the United States and South Vietnam for the failure to achieve a workable peace.

Gelb and Betts conclude that the basic lesson of Vietnam is that the system worked. No need exists for structural changes in the policy process, nor for new doctrines, formulas, ideologies. What is needed is simply pragmatism among the final decision arbitrators. Here Halberstam and Gelb and Betts have something in common. 
One other book, Guenter Lewy's America in Vietnam (1978), could have been listed among the most significant studies, although it is less a thematic explanation than a relook at some basic issues of the conflict. Lewy was the first scholar to gain access to Defense Department files on the war. His research in these records convinced him that American policy was unwise and inept; but it was not illegal nor immoral. He presents a massive array of data and statistics to verify his claim and to refute the cherished myths of leftist anti-war critics. Reviewers have expressed mixed reactions. Some have labeled the book a whitewash, an apology for the war, and an attempt to sell the conflict. More favorable and accurate commentators note that it scratches the surface of a large topic, breaks new ground, provides new evidence, and reopens many important issues of the war. Although it is too particular and intensive to be good auxiliary reading in an undergraduate Vietnam course, it is a book with which all students should be familiar.

A few other important topics and books must be mentioned. Douglas Pike is the acknowledged authority on the communist forces. His Viet Cong: The Organization and Techniques of the National Liberation Front of South Vietnam (1966) is a classic; War, Peace, and the Viet Cong (1969) and The Viet Cong Strategy of Terror ( $1 \overline{970})$ expand his analysis. His brief paperback, History of the Vietnamese Communist Party (1978), which surveys and updates the earlier work of such experts as Bernard Fall, P. J. Honey, Jean Lacouture, George Tanham, Joseph J. Zasloff, Dennis Duncanson, David G. Marr, John T. McAlister, Alexander Woodside, and William Duiker, is a valuable source for the undergraduate student: Robert Turner's Vietnamese Communism: Its Origins and Development (1975) is a more detailed but less balanced alternative. Jon M. Van Dyke's North Vietnam's Strategy for Survival (1972), William S. Turley's (ed.) Vietnamese Communism in Comparative Perspective (1980), and William Darry 1 Henderson's Why the Viet Cong Fought: A Study of Motivation and Contro1 in a Modern Army in Combat (1979) expand our knowledge. Jeffrey Race's War Comes to Long An: Revolutionary Conflict in a Vietnamese Province (1972), William R. Andrews' The Village War: Activities in Dihn Tuong Province, 19601964 (1973), and James W. Trullinger, Jr.'s Village at War: An Account of Revolution in Vietnam (1980) are worthwhile microcosmic studies.

The "final days" and post-1975 Vietnam is a critical period which must be addressed in a Vietnam course. A number of eyewitness accounts of the time and events are available, and several more scholarly studies are in progress. Among the best now in print are Denis A. Warner's Certain Victory: How Hanoi Won the War (1978), the memoirs of the conservative Australian journalist who served in Vietnam from 1949 until the end in 1975; Stephan T. Hosmer, et al., The Fall of South Vietnam: Statements by Vietnamese Military and Civilian Leaders (1980), a fascinating compendium; Saigon politican Tran Van Don's Our Endless War: Inside Vietnam (1979); and Nguyen Cao Ky's How We Lost the

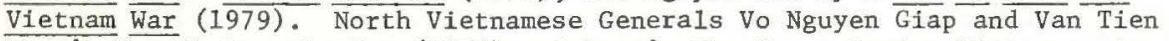
Dung's How We Won the War (1976) and Dung's The Great Spring Victory: An Account of the Liberation of South Vietnam (1977) are amazingly candid. Among the works in progress supposedly is a political novel by television commentators Bernard and Marvin Kalb entitled The Last Ambassador.

No book on the "final days" is more interesting or important than Frank Snepp's controversial Decent Interval (1977). Among the last to leave beleagured Saigon, Snepp, a high level CIA analyst, witnessed the chaos and travesty of the final weeks and days. He contends that Ambassador Graham Martin and CIA Station Chief Thomas Polgar bear grave responsibility for the delayed and bungled evacuation. They misread the crises and exercised poor judgment and leadership in the final days. While all Americans eventually were evacuated in the final hours, thousands of loyal Vietnamese employees were left behind and sensitive files including the names of Vietnamese with American 
intelligence affiliations were not destroyed. The end was consistent with the long, frustrating, and mismanaged war experience.

After the evacuation, Snepp sought permission to compile an After Action Report, an account of the lessons of the experience. When his request was repeatedly denied and the government attempted to cover up the debacle, Snepp, in violation of his CIA oath of secrecy, wrote and clandestinely arranged publication of the book. Even if Snepp's actions cannot be condoned, this is a story which needed to be told. It is a fascinating and lesson-filled account.

The saga of the Vietnamese refugees also must be told. While the bloodbath did not begin immediately, eventually the new communist leadership turned the re-education centers and "new economic zones" into Asian gulags. The persecution of the ethnic Chinese, the boat people, and the land exodus are all part of the poignant story. Many personal dramas from the survivors of these experiences are beginning to appear in print. Darell Montero's and Marsha I. Weber's Vietnamese Americans: Patterns of Resettlement and Socioeconomic Adaptation in the United States (1978), and Bruce Grant's The Boat People (1980), are early attempts to deal with one aspect of this issue.

Some attention also must be given to the refugees and brutality in Cambodia/Kampuchea. Phnom Penh fell to the communists at the same time as Saigon, and the Khmer Rouge quickly revealed themselves to be one of the most barbaric regimes in world history. John Barron's and Anthony Paul's Murder of a Gentle Land (1977) and Francois Ponchaud's Cambodia: Year Zero (1978)-originally published in French in 1976--detail the brutal genocide conducted by the young conquerors. While the Khmer Rouge bear total responsibility for their inhumanity, British journalist William Shawcross's controversial Sideshow: Kissinger, Nixon and the Destruction of Cambodia (1979) argues that United States actions accelerated the communists ascendency. The book is a burning attack upon Nixon's and Kissinger's handling of Cambodia policy, particularly of the Cambodian Incursion of 1970. The book has inspired some furor. Reviewers of the caliber of Harrison Salisbury, Bill Moyers, and General James Gavin call it a major exposé and an incriminating indictment of Nixon-Kissinger; other reviewers dismiss the work as a virulent tract. Kissinger responds (in a quotation printed on the cover of the paperback edition) that he is "astonished that a book so inaccurate and distorted has been accepted as gospe1 truth!"

Fina11y, a word must be said about the military aspects and lessons of the Vietnam War. Although this is probably the least important aspect for an undergraduate liberal arts course on Vietnam, it should not be entirely neglected. An adequate military history of the war remains to be written. Dave Richard Palmer's Summons of the Trumpet (1978) is a brief look jat certain military aspects with an emphasis upon the lessons; it is interesting but far from definitive. Neither is popular-audience military historian Edgar O'Ba1lance's The Wars in Vietnain, 1954-1973 (1976). Veteran war chronicler S. L. A. Marshall has written four combat accounts, and several other ground and air war narratives exist. Ray Bonds (ed.), The Vietnam War: The I1lustrated History of the Conflict in Southeast Asia (1979), with its 550 pictures and numerous other pictorials, is engaging. The military memoirs of leaders such as Generals William Westmoreland and Lewis Walt, Admirals U.S. Grant Sharp and Elmo Zumwalt, and Colonels Anthony Herbert and William Corson are in print, and a biography on the legendary Colonel John Paul Vann is in preparation.

But far more interesting are the accounts of ordinary soldiers. A significant number of books have come from the more than three million G.I.s who served in Vietnam. Some are memoirs; others are novels or other forms of fictionalized narrative. Most are fascinating and disturbing reading which 
bring the war home to the reader. Students find them captivating. Among the best are Charles Coe's Young Man in Vietnam (1968), Josiah Bunting's The Lionheads (1972), Tim o'Brien's If I Die in a Combat Zone (1973) and Going After Cacciato (1978), Ron Kovic's Born on the Fourth of July (1976), Charles Anderson's The Grunts (1976), Larry Heinemann's Close Quarters (1977), Philip Caputo's A Rumor of War (1977), James Webb's Fields of Fire (1978), Winston Groom's Better Times Than These (1978), Frederick Downs's The Killing Zone (1978), Gustav Hasford's The Short-Timers (1979), Jim Morris's War Story (1979), and combat journalist Michael Herr's Dispatches (1977).

The former POWs also have a story to tell. The number of memoirs grows yearly. John G. Hubbell, et al., P.O.W.: A Definitive History of the American Prisoner of War Experience in Vietnam, 1964-1973 (1976), Stephen A. Rowan's They Wouldn't Let Us Die: The Prisoners of War Tell Their Story (1973), and Zalin Grant's Survivors (1975) are the most comprehensive accounts. Scott Blakey's Prisoner at War: The Survival of Commander Richard A. Stratton (1978) and James $\mathbb{N}$. Rowe's Five years to Freedom (j.971) are the best individual offerings. Douglas L. Clarke's The Missing Man: Politics and the M.I.A. (1979) and Larry J. O'Daniel's Missing in Action: Trail of Deceit (1979) discus the overlooked men listed as missing in action.

Other significant studies of the military lessons include Robert Gallucci's Neither War Nor Peace: The Politics of American Military Policy in Vietnam (1975); W. Scott Thompson and Donaldson D. Frizzell, eds., The Lessons of Vietnam (1977), the product of a symposium on "The Military Lessons of Vietnam"; retired Brigadier General Douglas Kinnard's The War Managers (1977), the result of a survey of the 173 general officers who held commands in Vietnam between 1965 and 1972; Lawrence M. Baskir's and William A. Strauss's devastating study of the inequities of the draft, Change and Circumstances: The Draft, the War, and the Vietnam Generation (1978); and James G. Thompson's Rolling Thunder: Understanding Policy and Program Failure (1980).

Long before the end of the war, the military was interested in preserving the immediate lessons of the Vietnam experience. At the end of the sixties, Army Chief of Staff William Westmoreland commissioned a series of Vietnam Studies focusing upon innovative logistic and administrative aspects of the war effort. Twenty-one monographs were ordered; the first was completed in 1971. The other services produced similar studies. But these were more memoirs and special topic accounts than official histories. At the end of the war, each service initiated its official history projects (following the precedents established at the end of World War II and the Korean Conflict). The first volumes of the Navy, Marines, Air Force, and Coast Guard accounts are in print; and the first book of the Army's projected 21-volume series will appear probably in 1981.7

The study of the Vietnam War belongs in the college curriculum. The subject can be integrated into a number of different courses. Diplomatic, military, and recent political courses should devote considerable time and attention to the subject. Vietnam should hold a prominent place in survey offerings. While this is increasingly the case in many history departments, in others the topic is treated lightly and superficially. This is unfortunate for a generation is maturing without proper understanding of one of the major forces shaping its contemporary world. Indeed, as argued earlier, Vietnam can serve as a microcosm of the forces of recent history. A strong case can be made for a complete course on the Vietnam experience. The course. lends itself to many approaches. 8 Abundant literature and resources exist for both the prospective instructor and the student of such a course. The interest and demand is present. A Vietnam course fulfills many roles and would be a strong addition to any history department. The subject now belongs to the historian; and we should seize it. 


\section{NOTES}

Henry Kissinger, White House Years (Boston, 1979), 54.

${ }^{2}$ Gaddis Smith, American Diplomacy During the Second World War, 1941-1945 (New York, 1965), 177 .

${ }^{3}$ For the most complete bibliographic essays of books on the war, see Peter Braestrup, "Vietnam as History," The Wilson Quarterly, II (Spring 1978), 178-187; and Joe P. Dunn, "In Search of Lessons: The Development of a Vietnam Historiography," Parameters: The Journal of the U.S. Army War College, XIX (December 1979), 28-40.

${ }^{4}$ The Boston Publishing Company has undertaken a multi-volume project entitled "The Vietnam Experience." Described in the publishing trade as "continuity books," the series will be somewhat like the "Ballatine Illustrated History of World War II" series or the Time-Life books. Each volume will rely heavily upon photographs (approximately 160 per book), maps, charts, and diagrams and will have a 50,000 word text. The first volume, Setting the Stage, available in March 1981, will survey Vietnamese history until 1945. At least twelve more volumes on such topics as the Ground War, the Air War in the North, Ho Chi Minh and Indochinese Communism, the War on the Homefront, and the Conflict in Laos and Cambodia, are planned.

${ }^{6}$ See the fascinating exchange over the book: Peter W. Rodman, "Sideswipe: Kissinger, Shawcross and the Responsibility for Cambodia: The Crafty Scholarship of William Shawcross," The American Spectator, XIV (March, 1981), 7-15; William Shawcross, "Shawcross Swipes Again: In Hot Pursuit of Peter Rodman," The American Spectator, XIV (July, 1981), 7-13; and Rodman, "Rodman Responds: Sideshow: Still Fraudulent After All These Words," The American Spectator, XIV (July, 1981), 14-17.

${ }^{7}$ See Eric C. Ludvigsen, "Vietnam--in 21 volumes," Army, XXVII (August, 1977), 30-32.

8 I have taught the course for several years in a variety of different ways: as primarily a lecture format, as a readings seminar, and as a research course built around student papers. Each approach has its merits. Incidentally, my audience has varied from an all military class, most of whom were Vietnam veterans, to my present students at a women's college.

\section{POSTSCRIPT}

Since the completion of this article, four important books which must be mentioned have appeared. Paul M. Kattenburg's The Vietnam Trauma in American Foreign Policy, 1945-75 (1980) is a new interpretative work which will take its place as a classic alongside FitzGerald, Halberstam, and Gelb and Betts. A foreign service officer for more than twenty years and the State Department's leading Vietnam expert in the 1950 s and early 1960s, Kattenburg was the leading early Vietnam critic within the decision-making structure. Approaching the war as "an intrinsic and inseparable part of our whole approach to the world in the post-World War II period," the book is a damning analysis of the Vietnam morass. The volume is packed with provocative commentary and insight in every chapter. The concluding chapter, "Vietnam as Lesson of History," is one of the best retrospects in print. When this book becomes available in paperback, it will be an exciting text for a Vietnam course.

Archimedes L.A. Patti was the OSS officer who led an American mission into Hanoi at the end of World War II. His Why Vietnam? Prelude to America's 
Albatross (1980) is an engaging account of those crucial months in late 1945, and a penetrating critique of lost opportunities. Wallace J. Thies's When Governments Collide: Coercion and Diplomacy in the Vietnam Conflict, 1964-1968 (1980) is a brillant study of bureaucratic politics, decision-making process, and coercion theory which analyzes why the Johnsonian policy of gradual

escalation and carefully orchestrated levels of pressure was destined to fail. William J. Duiker's The Comnunist Road to Power in Vietnam (1981) is a valuable new contribution.

A final book has attracted wide attention; however, it is extremely poor scholarship and might even be called a fraud. The author of Self-Destruction: The Disintegration and Decay of the United States Army during the Vietnam Era (1981) employs the pseudonym Cincinnatus as his pen name for his scathing indictment of General William Westmoreland and the rest of the highest military leadership in Vietnam. Cincinnatus claimed to be a senior field-grade officer, veteran of Korea and Vietnam, currently assigned to the Pentagon. In fact, he has been identified as Cecil B. Currey, a history professor and reserve officer chaplain who spends two weeks each year at the Pentagon. He did not serve in Korea or Vietnam. This aside, the book is full of gross factual inaccuracies, unsubstantiated assertions, and unscholarly attributions. The author's charges might be worthy of consideration, but this book is not. While much of what the author infers is probably true, the case will not be made by such a bad book. 